\title{
IDIOPATHIC SCOLIOSIS: EVALUATION OF LOSS OF CORRECTION IN POSTOPERATIVE FOLLOW-UP
}

\author{
ESCOLIOSE IDIOPÁTICA: AVALIAÇÃO DA PERDA DE CORREÇÃO EM SEGUIMENTO \\ PÓS-OPERATÓRIO
}

\author{
ESCOLIOSIS IDIOPÁTICA: EVALUACIÓN DE LA PÉRDIDA DE LA CORRECCIÓN \\ EN EL SEGUIMIENTO POSTOPERATORIO
}

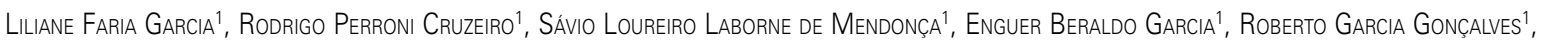
Sebastiāo Vasconcelos de Souza', Enguer Beraldo Garcia Júnior²

\begin{abstract}
Objective: To evaluate the postoperative loss of scoliosis correction using third-generation instrumental, comparing the immediately postoperative period, and the last visit of the patients operated on from 2002 to 2010 . Method: This was a cross-sectional study, conducted by analysis of medical records, in which 45 patients undergoing scoliosis correction were included. Variables were evaluated preoperatively, immediately postoperatively and in the last follow-up visit after surgery. Statistical analysis of data was performed in PASW program, with a significance level of 95\%. Results: Among the 45 patients studied, $88.9 \%$ were female and $82.8 \%$ were in the skeletally immature group. The mean pre-operative Cobb was $57^{\circ}$, the postoperative was $6.5^{\circ}$ and at the last visit, it was $7.04^{\circ}$. There was no statistic difference between postoperative Cobb angle and that at the last examination $(p=0.176)$. Conclusion: There was no significant loss of scoliosis correction loss between the immediate postoperative and the final radiographic evaluation.
\end{abstract}

Keywords: Scoliosis/diagnosis; Scoliosis/surgery; Scoliosis/radiography; Surgical procedures, operative; Bone screws.

\section{RESUMO}

Objetivo: Avaliar a perda de correção da escoliose tratada cirurgicamente, com instrumental de terceira geração, comparando o pós-operatório imediato e a última consulta dos pacientes operados entre 2002 e 2010. Métodos: Trata-se de um estudo transversal, realizado por meio de análise de prontuários, no qual foram incluídos 45 pacientes submetidos à correção de escoliose. As variáveis foram avaliadas no pré-operatório, pós-operatório imediato e na última consulta de seguimento. A análise estatística dos dados foi realizada no programa PASW, com nível de significância de 95\%. Resultados: Dentre os 45 pacientes estudados, 88,9\% são do sexo feminino e $82,8 \%$ estão no grupo de imaturidade esquelética. O Cobb médio no pré-operatório foi de $57^{\circ}$, no pós-operatório foi de $6,5^{\circ}$ e na última consulta, foi de $7,04^{\circ}$. Na comparação do ângulo de Cobb no pós-operatório e na última consulta não foi encontrada diferença estatisticamente significante, $p=0,176$. Conclusão: Não houve perda significativa da correção da escoliose entre o pós-operatório imediato e a última avaliação radiográfica.

Descritores: Escoliose/diagnóstico; Escoliose/cirurgia; Escoliose/radiografia; Procedimentos cirúrgicos operatórios; Parafusos ósseos.

\section{RESUMEN}

Objetivo: Evaluar la pérdida de corrección de la escoliosis tratada quirúrgicamente, con instrumental de tercera generación, comparando el postoperatorio inmediato y la última consulta de los pacientes operados entre 2002 y 2010. Métodos: Se trata de un estudio transversal, realizado por medio de análisis de fichas médicas, en el cual fueron incluidos 45 pacientes sometidos a la corrección de escoliosis. Las variables fueron evaluadas en el preoperatorio, postoperatorio inmediato y en la última consulta de seguimiento. El análisis estadístico de Ios datos se realizó en el programa PASW, con nivel de significancia de 95\%. Resultados: Entre los 45 pacientes estudiados, $88,9 \%$ son del sexo femenino y $82,8 \%$ están en el grupo de inmadurez esquelética. El Cobb promedio fue $57^{\circ}$ en el preoperatorio; $6,5^{\circ}$ en el postoperatorio y 7,04 en la última consulta. En la comparación del ángulo de Cobb, en el postoperatorio y en la última consulta, no se encontró diferencia estadísticamente significativa, $p=0,176$. Conclusión: No hubo pérdida importante de la corrección de la escoliosis entre el posoperatorio inmediato y la última evaluación radiográfica.

Descriptores: Escoliosis/diagnóstico; Escoliosis/cirugía; Escoliosis/radiografía; Procedimientos quirúrgicos operativos; Tornillos óseos.

\section{INTRODUCTION}

Scoliosis has been defined as a deviation of the spine in the coronal and horizontal planes, ${ }^{1}$ with idiopathic scoliosis being the most common deviation. ${ }^{2}$ In its milder forms, scoliosis may only cause changes in the shape of the trunk, but when severe, it can evolve with neurological, cardiac, and pulmonary involvement.

The Scoliosis Research Society recommends that idiopathic scoliosis be classified based on the age at onset due to the difference in evolution of subtypes: infantile scoliosis arises from birth to three years of age; juvenile arises between four and ten years; and adolescent arises between the age of ten and skeletal maturity, which for this study was considered to be eighteen to facilitate statistical interpretation.

The prevalence of scoliosis is $1-2 \%$ in the general population,

1. Department of Orthopedics and Traumatology, Santa Casa de Misericórdia de Belo Horizonte, Belo Horizonte, MG, Brazil.

2. Universidade Unifenas, Belo Horizonte, MG, Brazil.

Study conducted at the Department of Orthopedics and Traumatology, Santa Casa de Belo Horizonte, MG, Brazil. Correspondence: Av. Francisco Sales, 427, Bairro Floresta, 30150 220, Belo Horizonte, MG, Brasil. enguerbg@ gmail.com 
and adolescent idiopathic scoliosis (AIS) is its most frequent presentation. ${ }^{3}$ The correction of scoliosis had a breakthrough with the beginning of the use of the Harrington instrumentation in $1962 .{ }^{4}$ in August 1978, Luque ${ }^{5}$ employed his instrumentation composed of $L$ rods and sublaminar steel wire, which was later combined with Harrington rods, giving them greater accuracy and stability. The innovation arose with the technique described in Paris in 1984 by Cotrel and Dubousset, ${ }^{6}$ using multiple hooks with superior and lateral covers, facilitating their assembly, allowing for implants at more levels, and thus better distributing the load between the vertebrae. ${ }^{7}$ The third generation instrumentation, fixating the three columns with transpedicular screws, provided the possibility of correcting the deformity in the coronal and axial planes.

Subsequently, it was modernized with the Colorado instrumentation. ${ }^{8,9}$ In 1998, a system similar to Colorado was developed in Brazil with long head screws, associated with clamps that offer a greater possibility of successfully correcting highly complex cases. ${ }^{10}$

The objective of this study is to assess the loss of correction of scoliosis treated surgically, with third generation instrumentation, comparing the immediate postoperative period and the last visit of the patients operated on between 2002 and 2010.

\section{METHODS}

This is a cross-sectional study, conducted through the analysis of medical records, in which the following variables were assessed: sex, age, the Cobb angle preoperatively, immediately postoperatively, and at the follow-up visit (mean of 7.1 years after surgery), and posterior or combined approach. A radiological study was performed using anteroposterior and lateral panoramic radiographs of the spine in the standing position for the preoperative and postoperative period evaluation. Only the values of the main curve were considered.

Prior to surgery, the fixation points and the direction of the force being applied on the segments and on each side, whether compression or distraction, were planned.

A posterior approach for the fixation and correction of the deformity was employed across the entire sample. Dissection of the spine, facectomy, complete resection of the articular cartilage and the capsule were performed to favor bone fusion and to make the deformity more flexible. Resection of the spinous processes and decortication of the posterior spine were then performed. Fragments were harvested for grafting the area of arthrodesis.

To pierce and pass the pedicle screws, an image intensifier was used for orientation, always focusing on the pedicle, mobilizing the device on three levels according to the degree of rotation; images in the frontal plane were considered with priority.

All patients were instrumented with rods, pedicle screws, and cross-locking devices to correct the approached segments. The intraoperative awakening test was used.

In 15 patients who had more severe and rigid curves, as evidenced by radiographs with a lateral tilt, the anterior approach was combined to improve corrigibility and bone stabilization. (Figure 1)

In the immediate postoperative period, cervical-thoracic-lumbosacral or thoracic-lumbosacral bracing was indicated for an average period of four months.

Later, a new radiographic study was performed to measure the deformity using the Cobb method. Measurements were performed in the immediate postoperative period and in the outpatient follow-up.

Initially, exploratory analysis was performed in order to characterize the patient sample; frequency distributions were used for qualitative variables, and descriptive measures (mean, standard deviation) for quantitative variables

As for the evaluation of differences between pre- and postoperative Cobb variable in the patients studied, the non-parametric Wilcoxon test was used.

The survey data were processed in the PASW statistical software. Statistically significant correlations were those with a $p$ value of less than 0.05 .

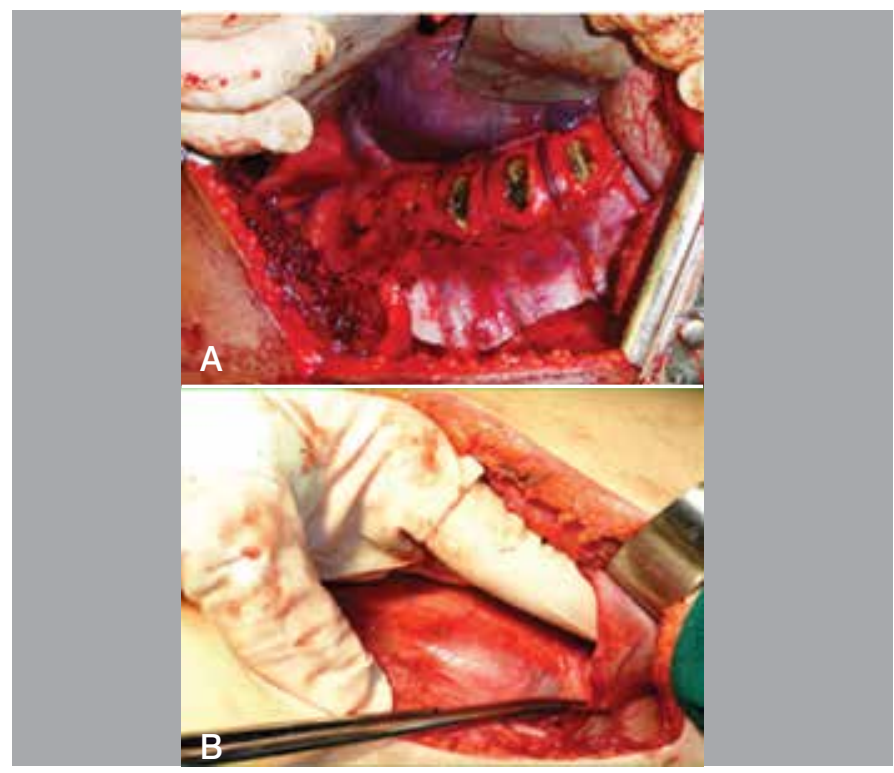

Figure 1. A) Anterior approach to the thoracic spine, thoracotomy with selective intubation, preservation of intercostal arteries and veins, epiphysiodesis of the vertebral body in the young adolescents with great potential for aggravation, vertebral mobilization and arthrodesis. B) Anterior approach of the thoracolumbar spine, with thoraco-phrenectomy, does not require selective intubation.

\section{RESULTS}

From 2002 to 2010, 169 records were filed with imaging exams of patients operated for adolescent idiopathic scoliosis. Of these, 45 were recently re-evaluated by the authors and included in the study. We excluded the rest because reassessment was not possible in time for analysis. The patients included are listed in Table 1.

The study sample is comprised of $5(11.1 \%)$ male and 40 (88.9\%) female patients. (Table 2) In relation to age, $82.2 \%$ of patients surveyed are at the stage of skeletal immaturity. Adult subjects make up the remaining percentage (17.8\%). (Table 2)

The mean preoperative Cobb was $57^{\circ}\left(+/-12.88^{\circ}\right)$, postoperatively it was $6.5^{\circ}\left(+/-3.36^{\circ}\right)$, and the last visit was $7.04^{\circ}\left(+/-3.55^{\circ}\right)$, considering the total sample. (Table 3 )

The mean values of the Cobb angle (pre, post, and last visit) showed no significant differences between males and females. The male group had a mean of $7.8^{\circ}$ postoperatively, whereas the female group had a mean of $6 \cdot 33^{\circ}$. (Table 4 )

By relating age with the Cobb angle, the group of adult patients was found to have Cobb values (pre, post, and last visit) similar to the group of skeletal immaturity. (Table 4)

Table 5 presents the pre- and postoperative results for the Cobb variable, which had a $p$ value less than the significance level of $5 \%$. Therefore, we reject the hypothesis that the medians of the Cobb variable are equal in the examined individuals. There is sufficient evidence to affirm that the preoperative Cobb angle in patients is greater than the Cobb angle in the postoperative period, as expected.

In comparing the Cobb angle postoperatively and at the last visit, there was no statistically significant difference found, $p=0.176$. (Table 5)

\section{DISCUSSION}

Over the past 20 years the treatment of idiopathic scoliosis has made great advances. The introduction of the third generation instrumentation and the use of pedicle screws have greatly increased the possibilities of correction and improvement of results.

With 21 patients, 16 women (76.2\%) and 5 men (23.8\%), with a mean preoperative Cobb angle of $62.38^{\circ}$ and a mean postoperative angle of $38.8^{\circ}$, Rodrigues et al. ${ }^{2}$ obtained correction of $61.36 \%$ of the initial curve. This paper cites no information about the postoperative follow-up. 
Table 1. Description of the variables for each patient.

\begin{tabular}{|c|c|c|c|c|c|c|c|c|}
\hline Patient & Age & Sex & \begin{tabular}{|c|} 
Surgery \\
date
\end{tabular} & \begin{tabular}{|c|} 
Last \\
evaluation
\end{tabular} & \begin{tabular}{|l|} 
Pre- \\
Cobb \\
\end{tabular} & \begin{tabular}{|l|} 
Post- \\
Cobb
\end{tabular} & \begin{tabular}{|l|} 
Last \\
Cobb \\
\end{tabular} & Approach \\
\hline 1 & 20 & $\mathrm{~F}$ & $05 / 07 / 02$ & $02 / 05 / 09$ & $60^{\circ}$ & $4^{\circ}$ & $4^{\circ}$ & $A+P$ \\
\hline 2 & 12 & $\mathrm{~F}$ & 07/10/06 & 05/29/09 & $90^{\circ}$ & $14^{\circ}$ & $14^{\circ}$ & $A+P$ \\
\hline 3 & 12 & $\mathrm{~F}$ & $12 / 05 / 03$ & $12 / 14 / 09$ & $35^{\circ}$ & $5^{\circ}$ & $5^{\circ}$ & $P$ \\
\hline 4 & 14 & $\mathrm{~F}$ & $01 / 10 / 05$ & $11 / 06 / 09$ & $63^{\circ}$ & $11^{\circ}$ & $7^{\circ}$ & $P$ \\
\hline 5 & 20 & $\mathrm{~F}$ & $08 / 02 / 06$ & 03/04/09 & $62^{\circ}$ & $8^{\circ}$ & $8^{\circ}$ & $A+P$ \\
\hline 6 & 24 & $\mathrm{~F}$ & 02/18/06 & 07/28/09 & $71^{\circ}$ & $3^{\circ}$ & $3^{\circ}$ & $A+P$ \\
\hline 7 & 35 & $\mathrm{~F}$ & $11 / 10 / 06$ & $09 / 27 / 10$ & $70^{\circ}$ & $6^{\circ}$ & $8^{\circ}$ & $A+P$ \\
\hline 8 & 15 & $\mathrm{~F}$ & $01 / 21 / 03$ & $06 / 12 / 09$ & $35^{\circ}$ & $11^{\circ}$ & $12^{\circ}$ & $\mathrm{P}$ \\
\hline 9 & 12 & $\mathrm{~F}$ & $01 / 18 / 06$ & $05 / 20 / 10$ & $38^{\circ}$ & $5^{\circ}$ & $6^{\circ}$ & $P$ \\
\hline 10 & 12 & $\mathrm{~F}$ & 07/20/05 & $03 / 25 / 10$ & $60^{\circ}$ & $8^{\circ}$ & $8^{\circ}$ & $P$ \\
\hline 11 & 15 & $\mathrm{~F}$ & $05 / 25 / 05$ & $12 / 27 / 08$ & $47^{\circ}$ & $10^{\circ}$ & $10^{\circ}$ & $P$ \\
\hline 12 & 18 & $\mathrm{~F}$ & $05 / 08 / 02$ & $04 / 12 / 11$ & $60^{\circ}$ & $6^{\circ}$ & $6^{\circ}$ & $A+P$ \\
\hline 13 & 11 & $\mathrm{~F}$ & $08 / 11 / 06$ & $02 / 08 / 10$ & $65^{\circ}$ & $5^{\circ}$ & $8^{\circ}$ & $\mathrm{P}$ \\
\hline 14 & 13 & $\mathrm{~F}$ & $02 / 25 / 06$ & 03/02/09 & $41^{\circ}$ & $2^{\circ}$ & $2^{\circ}$ & $P$ \\
\hline 15 & 12 & $\mathrm{~F}$ & $07 / 16 / 07$ & $01 / 22 / 10$ & $52^{\circ}$ & $10^{\circ}$ & $10^{\circ}$ & $P$ \\
\hline 16 & 14 & $\mathrm{~F}$ & $02 / 23 / 08$ & $01 / 11 / 11$ & $60^{\circ}$ & $3^{\circ}$ & $3^{\circ}$ & $P$ \\
\hline 17 & 17 & $\mathrm{~F}$ & 04/19/08 & $07 / 12 / 10$ & $73^{\circ}$ & $2^{\circ}$ & $3^{\circ}$ & $A+P$ \\
\hline 18 & 15 & $\mathrm{~F}$ & 04/16/08 & 07/31/09 & $45^{\circ}$ & $8^{\circ}$ & $8^{\circ}$ & $P$ \\
\hline 19 & 11 & $\mathrm{~F}$ & 01/06/08 & $04 / 26 / 10$ & $49^{\circ}$ & $10^{\circ}$ & $6^{\circ}$ & $P$ \\
\hline 20 & 13 & $\mathrm{~F}$ & 06/16/08 & $12 / 14 / 10$ & $68^{\circ}$ & $7^{\circ}$ & $8^{\circ}$ & $A+P$ \\
\hline 21 & 19 & $\mathrm{~F}$ & $01 / 31 / 08$ & $07 / 27 / 09$ & $48^{\circ}$ & $7^{\circ}$ & $5^{\circ}$ & $P$ \\
\hline 22 & 19 & $\mathrm{~F}$ & 02/16/08 & 03/10/10 & $48^{\circ}$ & $5^{\circ}$ & $5^{\circ}$ & $P$ \\
\hline 23 & 17 & $\mathrm{M}$ & $12 / 07 / 08$ & 06/22/09 & $62^{\circ}$ & $8^{\circ}$ & $8^{\circ}$ & $P$ \\
\hline 24 & 16 & $M$ & $11 / 06 / 06$ & $03 / 11 / 10$ & $72^{\circ}$ & $7^{\circ}$ & $17^{\circ}$ & $A+P$ \\
\hline 25 & 14 & $\mathrm{~F}$ & $10 / 27 / 08$ & $12 / 11 / 09$ & $44^{\circ}$ & $8^{\circ}$ & $10^{\circ}$ & $P$ \\
\hline 26 & 15 & $\mathrm{~F}$ & 01/17/09 & $03 / 25 / 10$ & $56^{\circ}$ & $9^{\circ}$ & $12^{\circ}$ & $\mathrm{P}$ \\
\hline 27 & 15 & $\mathrm{~F}$ & 01/12/09 & $07 / 27 / 10$ & $89^{\circ}$ & $12^{\circ}$ & 12 & $A+P$ \\
\hline 28 & 15 & $\mathrm{~F}$ & $05 / 12 / 08$ & 03/16/09 & $52^{\circ}$ & $11^{\circ}$ & $11^{\circ}$ & $P$ \\
\hline 29 & 16 & $\mathrm{~F}$ & 03/29/09 & $10 / 31 / 10$ & $50^{\circ}$ & $6^{\circ}$ & 6 & $\mathrm{P}$ \\
\hline 30 & 14 & $M$ & 07/15/09 & $05 / 17 / 10$ & $56^{\circ}$ & $5^{\circ}$ & $5^{\circ}$ & $\mathrm{P}$ \\
\hline 31 & 14 & $\mathrm{~F}$ & 09/22/08 & 04/05/09 & $42^{\circ}$ & $1^{\circ}$ & $1^{\circ}$ & $P$ \\
\hline 32 & 12 & $\mathrm{~F}$ & $07 / 11 / 09$ & $10 / 14 / 07$ & $50^{\circ}$ & $5^{\circ}$ & $5^{\circ}$ & $P$ \\
\hline 33 & 12 & $\mathrm{~F}$ & $04 / 12 / 09$ & $11 / 03 / 10$ & $76^{\circ}$ & $1^{\circ}$ & $5^{\circ}$ & $\mathrm{P}$ \\
\hline 34 & 23 & $\mathrm{~F}$ & 04/13/07 & $01 / 25 / 11$ & $43^{\circ}$ & $2^{\circ}$ & $2^{\circ}$ & $P$ \\
\hline 35 & 14 & $\mathrm{~F}$ & $12 / 10 / 08$ & $12 / 16 / 10$ & $69^{\circ}$ & $5^{\circ}$ & $5^{\circ}$ & $A+P$ \\
\hline 36 & 14 & $\mathrm{~F}$ & 06/20/02 & 07/14/09 & $47^{\circ}$ & $5^{\circ}$ & $5^{\circ}$ & $\mathrm{P}$ \\
\hline 37 & 17 & $M$ & $12 / 13 / 08$ & $02 / 17 / 11$ & $61^{\circ}$ & $7^{\circ}$ & $7^{\circ}$ & $A+P$ \\
\hline 38 & 15 & $\mathrm{~F}$ & $08 / 23 / 08$ & $07 / 12 / 10$ & $62^{\circ}$ & $3^{\circ}$ & $5^{\circ}$ & $A+P$ \\
\hline 39 & 13 & $\mathrm{~F}$ & $10 / 23 / 07$ & $12 / 22 / 09$ & $64^{\circ}$ & $11^{\circ}$ & $11^{\circ}$ & $P$ \\
\hline 40 & 16 & $\mathrm{~F}$ & 07/19/09 & $02 / 01 / 10$ & $70^{\circ}$ & $15^{\circ}$ & $15^{\circ}$ & $\mathrm{A} / \mathrm{P}$ \\
\hline 41 & 17 & $\mathrm{~F}$ & $02 / 08 / 10$ & $02 / 16 / 11$ & $49^{\circ}$ & $3^{\circ}$ & $6^{\circ}$ & $\mathrm{P}$ \\
\hline 42 & 12 & $\mathrm{~F}$ & $12 / 18 / 10$ & $02 / 07 / 11$ & $65^{\circ}$ & $3^{\circ}$ & $3^{\circ}$ & $\mathrm{P}$ \\
\hline 43 & 14 & $\mathrm{~F}$ & $07 / 03 / 10$ & $01 / 25 / 11$ & $45^{\circ}$ & $2^{\circ}$ & $2^{\circ}$ & $\mathrm{P}$ \\
\hline 44 & 22 & $M$ & $01 / 20 / 10$ & $01 / 24 / 11$ & $72^{\circ}$ & $12^{\circ}$ & $12^{\circ}$ & $A+P$ \\
\hline 45 & 15 & $\mathrm{~F}$ & 03/20/10 & $11 / 16 / 10$ & $40^{\circ}$ & $5^{\circ}$ & $5^{\circ}$ & $P$ \\
\hline
\end{tabular}

Table 2. Frequency distribution of patients according to demographic characteristics.

\begin{tabular}{c|c|c}
\hline Variables & N & $\%$ \\
\hline Sex & & \\
\hline Female & 40 & 88.9 \\
\hline Male & 5 & 11.1 \\
\hline Age & & \\
\hline Skeletal immaturity & 37 & 82.2 \\
\hline Adult & 8 & 17.8 \\
\hline Total & 45 & 100 \\
\hline \multicolumn{2}{|l}{}
\end{tabular}

Table 3. Cobb angle assessment for the total patient sample.

\begin{tabular}{c|c|c|c|c}
\hline Cobb & N & $\begin{array}{c}\text { Mean } \pm \text { standard } \\
\text { deviation }\end{array}$ & Median & $\begin{array}{c}\text { Minimum - } \\
\text { maximum }\end{array}$ \\
\hline Preoperative Cobb & 45 & $57^{\circ} \pm 12.88^{\circ}$ & $60.0^{\circ}$ & $35.0^{\circ}-89^{\circ}$ \\
\hline Postoperative Cobb & 45 & $6.5^{\circ} \pm 3.36^{\circ}$ & $6.0^{\circ}$ & $1.0^{\circ}-15.0^{\circ}$ \\
\hline Cobb at last visit & 45 & $7.04^{\circ} \pm 3.55^{\circ}$ & $6.0^{\circ}$ & $1.0^{\circ}-17.0^{\circ}$ \\
\hline
\end{tabular}

Table 4. Cobb angle assessment by sex and age.

\begin{tabular}{c|c|c|c|c}
\hline \multirow{2}{*}{ Variable } & \multicolumn{2}{|c|}{ Sex } & \multicolumn{2}{c}{ Age } \\
\cline { 2 - 5 } & Male $(\mathbf{n = 5 )}$ & Female $(\mathbf{n}=\mathbf{4 0 )}$ & $\begin{array}{c}\text { Skeletal } \\
\text { immaturity }(\mathbf{n = 3 7 )}\end{array}$ & Adult (n=8) \\
\hline $\begin{array}{c}\text { Preoperative } \\
\text { Cobb }\end{array}$ & $64.6^{\circ} \pm 7.12^{\circ}$ & $56.05^{\circ} \pm 13.17^{\circ}$ & $56.51^{\circ} \pm 13.24^{\circ}$ & $59.25^{\circ} \pm 11.60^{\circ}$ \\
\hline $\begin{array}{c}\text { Postoperative } \\
\text { Cobb }\end{array}$ & $7.8^{\circ} \pm 2.58^{\circ}$ & $6.33^{\circ} \pm 3.44^{\circ}$ & $6.62^{\circ} \pm 3.48^{\circ}$ & $6.38^{\circ} \pm 2.97^{\circ}$ \\
\hline $\begin{array}{c}\text { Cobb at last } \\
\text { visit }\end{array}$ & $9.8^{\circ} \pm 4.76^{\circ}$ & $6.7^{\circ} \pm 3.29^{\circ}$ & $7.24^{\circ} \pm 3.65^{\circ}$ & $6.13^{\circ} \pm 3.10^{\circ}$ \\
\hline
\end{tabular}

Table 5. Comparison of mean preoperative, postoperative, and last visit Cobb scores.

\begin{tabular}{c|c|c|c}
\hline \multirow{2}{*}{ Cobb } & \multicolumn{3}{|c}{ Results } \\
\cline { 2 - 2 } & $\begin{array}{c}\text { Scores } \\
\text { median }\end{array}$ & \multirow{2}{*}{ P value } & Conclusion \\
\hline Preoperative Cobb & $60^{\circ}$ & \multirow{2}{*}{$0.000^{* *}$} & Pre-Cobb > Post-Cobb \\
Postoperative Cobb & $6^{\circ}$ & 0.176 & $\begin{array}{c}\text { Post-Cobb }=\text { Last visit } \\
\text { Cobb }\end{array}$ \\
\hline Postoperative Cobb & $6^{\circ}$ & & \\
\hline Cobb at last visit & $6^{\circ}$ & &
\end{tabular}

Significance probabilities ( $p$ value) refer to the Wilcoxon test. The $p$ values in bold indicate significan differences. The significant results were identified with asterisks according to the level of significance, namely: $p$ value $<0: 01$ ** (confidence level of 99.0\%) and $p$ value $<0.05 *$ (confidence level of 95.0\%). Source: Research data.

With 25 patients, 23 women (92\%) and two men (8\%), and with mean follow-up of 23.7 months, Gotfryd et al. ${ }^{11}$ found an average preoperative Cobb angle of $54.9^{\circ}$ and an average postoperative angle of $16.7^{\circ}$, achieving a correction of $69.9 \%$.

Pratali et al. ${ }^{12}$ treated 17 patients, 16 women (94.11\%) and one man $(5.88 \%)$ with a mean preoperative Cobb angle of $53.4^{\circ}$ and $15.2^{\circ}$ postoperatively. The mean correction achieved was $71 \%$ of the initial curve. In their series, two patients (11.76\% of total patients) presented complications.

Comparing the efficiency and safety of the surgical treatment of idiopathic scoliosis in skeletally immature patients and adults (closed triradiate cartilage), Yuan et al. ${ }^{13}$ reviewed the results of 40 patients (16 skeletally immature and 24 adults), showing good correction and maintenance of results in both groups. However, there were larger corrections and greater loss of correction in the skeletally immature group. In our study, a slightly higher loss of correction was also observed in the follow-up of skeletally immature patients.

After a minimum follow-up of 3 years postoperatively, Lehman et al. ${ }^{14}$ showed a $2.14^{\circ}$ mean loss of correction of the Cobb angle (a $12.73 \%$ loss).

Guanyu et al. ${ }^{15}$ published a case series of 27 patients with adolescent idiopathic scoliosis surgically treated with pedicle screws. After 2 years of follow-up, there was an average loss of $2.5^{\circ}$ on the final correction of the Cobb angle, corresponding to $19.23 \%$.

Garcia et al. ${ }^{16}$ reported a positive experience in the correction of adolescent idiopathic scoliosis of 36 patients, using third generation instrumentation.

In our series, 45 patients were followed up for a mean period of 7.1 years and a minimum of 1 year, with a mean correction of $89.73 \%$ and an average loss on follow-up of only $0.54^{\circ}$ (average Cobb in the immediate postoperative period: $6.5^{\circ}$ and at the last visit: $7.04^{\circ}$ ). There was no statistically significant difference when comparing the skeletally immature patients with the adults. (Figures 2, 3, 4, and 5) 


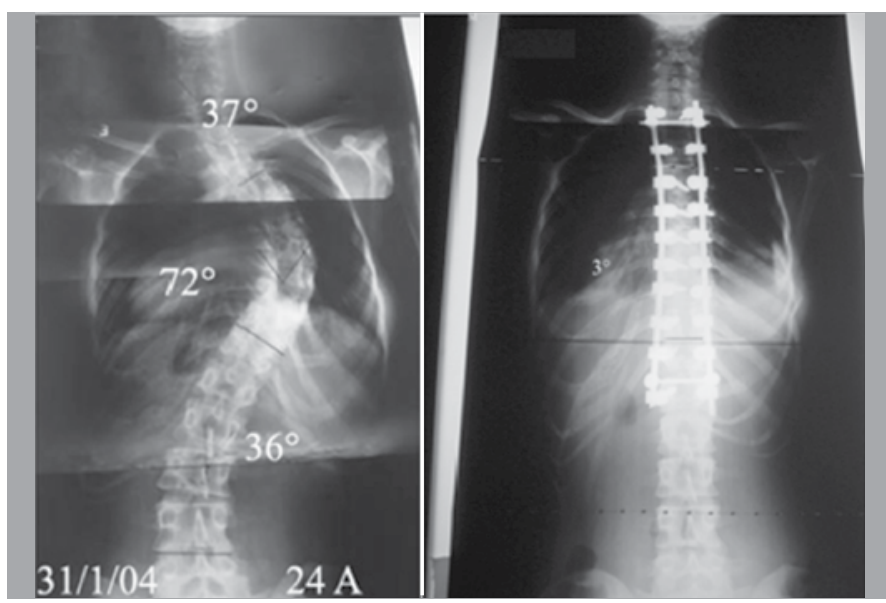

Figure 2. Patient 6 , female, radiograph before and after surgery for adolescent idiopathic scoliosis, $1 \mathrm{~A} \mathrm{~N}$, refused surgery at age 17, at age 24 opted for correction, stiffer curve, anterior and posterior approach was performed.

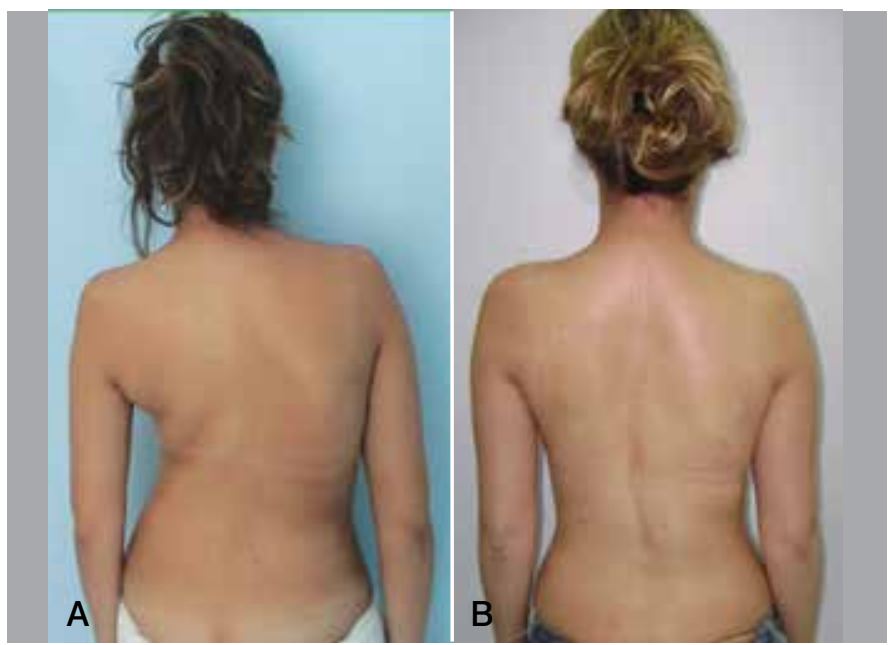

Figure 3. Patient 6 , A) before surgery on 2/18/06, B) 7/28/09, over 3 years postoperatively, showing good correction and trunk balance.

We believe that this loss of only $0.54^{\circ}$ of correction is due to a posterior approach with rigid instrumentation, using a greater number of fixation points, large caliber and long screws, covering the three columns, with a combination of anterior approach in the more severe and rigid curves, particularly in cases of younger adolescents with great potential for worsening and risk of the crankshaft phenomenon.

\section{REFERENCES}

1. Moe JH, Byrd JA. Idiopathicscoliosis. In: Lonsteins JE, Winter RB, Bradford DS RB, Olgivie JW, editors. Moe's textbook of scoliosis and other spinal deformities. 2nd ed. Philadelphia: Saunders; 1987. p. 191-232.

2. Rodrigues LMR, Yonezaki AM, Ueno FH, Nicolau RJ, Abreu LC, Filho EVS, et al. Escoliose Idiopática do adolescente: análise do grau de correção obtido com o uso de parafusos pediculares. Arq Bras Ciênc Saúde. 2009;35(1):1-11.

3. Lonstein JE, Bjorklund S, Wanninger MH, Nelson RP. Voluntary school screening for scoliosis in Minnesota. J Bone Joint Surg Am. 1982;64(4):481-8.

4. Harrington PR. Treatment of scoliosis: correction and internal fixation by spine instrumentation. June 1962. J Bone Joint Surg Am. 2002;84-A(2):316.

5. Luque ER. Surgical immobilization of the spine in elderly patients. Clin Orthop. 1978;(133):273-4.

6. CotrelY, Dubousset J. A new technic for segmental spinal osteosynthesis using the posterior approach. Rev Chir Orthop Reparatrice Appar Mot. 1984:70(6):489-94

7. Suk SI, Lee CK, Min HJ, Cho KH, Oh JH. Comparison of Cotrel-Dubousset pedicle screws and hooks in the treatment of idiopathic scoliosis. Int Orthop. 1994;18(6):341-6.

8. Delorme $\mathrm{S}$, Labelle $\mathrm{H}$, Aubin $\mathrm{CE}$, de Guise JA, Rivard $\mathrm{CH}$, Poitras $\mathrm{B}$, et al. Intraoperative comparison of two instrumentation techniques for the correction of adolescent idiopathic scoliosis. Rod rotation and translation. Spine (Phila Pa 1976). 1999;24(19):2011-7.

9. Delorme S, Labelle H, Aubin CE, de Guise JA, Rivard CH, Poitras B, et al. A three-dimensional radiographic comparison of Cotrel-Dubousset and Colorado instrumentations for
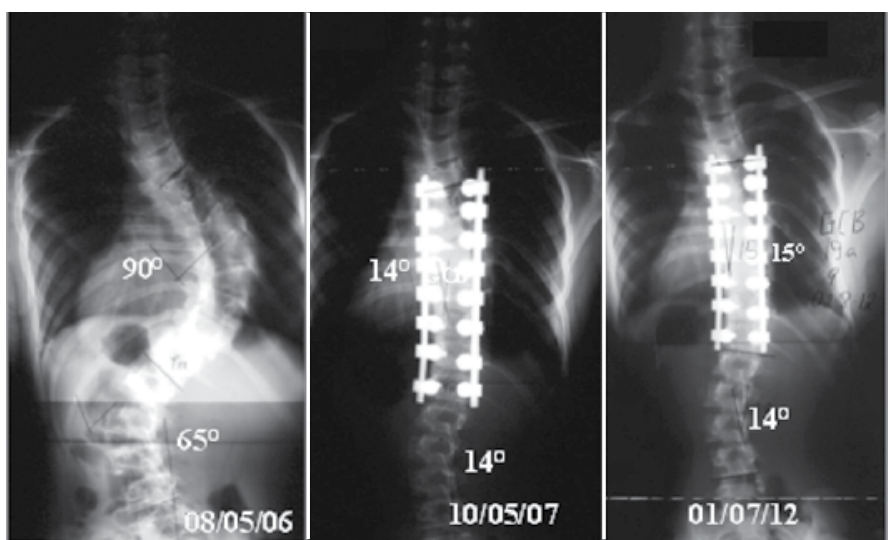

Figure 4. Patient 2, female, 3 B N, 12 years, menarche absent, Risser zero, great evolutionary potential, we opted for a selective approach of only the medium thoracic curve (more structured), epiphysiodesis and anterior arthrodesis were performed to prevent the crankshaft phenomenon, ending with the correction by posterior approach. From left to right, the preoperative radiographs, those in the immediate postoperative period, and after six years.

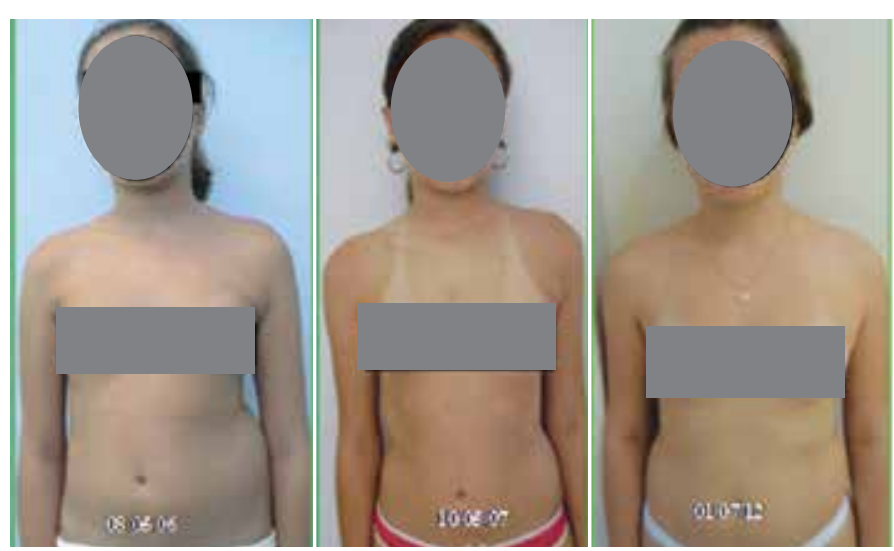

Figure 5. Patient 2, the case in Figure 4, preoperative photos at age 12, one year later, and at age 18, the correction and trunk balance are observable, and in the picture on the right maintenance of correction after 6 years.

\section{CONCLUSION}

We conclude that in this group of patients there was no statistically significant correction loss after surgical treatment of adolescent idiopathic scoliosis, even after long-term follow-up.

All authors declare no potential conflict of interest concerning this article.

the correction of idiopathic scoliosis. Spine (Phila Pa 1976). 2000;25(2):205-10.

10. Garcia EB, Ferreira DC, Moreira FA, Nascimento MBPG, Gonçalves RG. Instrumentação cirúrgica de colorado para escoliose idiopática do adolescente. Rev Min Ortop Traumatol. 2004;2:37-41.

11. Gotfryd AO, Franzin FJ, Raucci G, Neto NJC, Poletto PR. Tratamento cirúrgico da escolióse idiopática do adolescente utilizando parafusos pediculares: Análise dos resultados clínicos e radiográficos. Coluna/Columna.2011;10(2):91-6.

12. Pratali RR, Neto MIR, Veiga IG, Pascoaline W, Cavali PTM, Santos MAM, et al. Parafuso pedicular: método para correção da deformidade na escolióse idiopática do adolescente. Coluna/Columna. 2010:9(3):271-276.

13. Yuan S, Qiu Y, Zhu F, Wang B, Yu Y, Zhu ZZ, et al. A comparative study on the surgical outcomes of spinal fusion in adolescent idiopathic scoliosis patients with or without triradiate cartilages closed. Zhonghua Wai Ke Za Zhi. 2011:49(5):414-8.

14. Lehman RA Jr, Lenke LG, Keeler KA, Kim YJ, Buchowski JM, Cheh G, et al. Operative treatment of adolescent idiopathic scoliosis with posterior pedicle screw-only constructs: minimum threeyear follow-up of one hundred fourteen cases. Spine (Phila Pa 1976). 2008;33(14):1598-604.

15. Cui G, Watanabe K, NishiwakiY, Hosogane N, Tsuji T, Ishii K, et al . Loss of apical vertebral derotation in adolescent idiopathic scoliosis: 2-year follow-up using multi-planar reconstruction computed tomography. Eur Spine J. 2012;21(6):1111-20.

16. Garcia EB,Gonçalves RG, Ribeiro GO,Garcia JF,Garcia LF. Instrumentação de terceira geração na escoliose idiopática do adolescente. Coluna/ Coluna. 2006;5 (1):35-42. 